\title{
Modification of functional quality of raw myofibril preparation obtained from water-washed mechanically recovered chicken meat
}

\author{
Jerzy Stangierski · Jan Zabielski • Bożena Grześ
}

Received: 28 June 2012/Revised: 18 December 2012/ Accepted: 19 December 2012/Published online: 10 January 2013

(C) The Author(s) 2013. This article is published with open access at Springerlink.com

\begin{abstract}
The aim of this study was to evaluate the effect of enzymatic modification of poultry myofibril preparation on its selected functional properties, that is, solubility of proteins, polymerisation rates of myosin and actin, thermodynamic properties and texture. The myofibril preparation (MP) from mechanically recovered chicken meat, produced by washing and separation of fat and connective tissue, was subjected to the action of the transglutaminase preparation added at $0.3 \%$ for a period ranging from 0.5 to $24 \mathrm{~h}$ at a temperature of $6-7^{\circ} \mathrm{C}$. The highest dynamics of a reduction in protein solubility was observed up to $3 \mathrm{~h}$ of incubation. A reduction in solubility influenced the electrophoretic pattern of proteins. A significant decrease was found for the intensity of the myosin band in successive modification periods. The addition of the enzyme also influenced a reduction in enthalpy for proteins of the tested system, occurring most dynamically up to $3 \mathrm{~h}$ of incubation. The most distinct changes characterising a high increase in all the texture parameters of MP were found in the initial period of enzymatic modification, that is, up to $4.5 \mathrm{~h}$.
\end{abstract}

Keywords Poultry surimi - Functional properties . Transglutaminase $\cdot$ Modification

\footnotetext{
J. Stangierski $(\bowtie) \cdot$ J. Zabielski

Department of Food Quality Management,

Poznan University of Life Sciences, Poznan, Poland

e-mail: stangier@up.poznan.pl

B. Grześ

Institute of Meat Technology, Poznan University

of Life Sciences, Poznan, Poland
}

\section{Introduction}

Surimi is an original Japanese term referring to a white, tasteless and odourless myofibril preparation, obtained from mechanically deboned fish meat, washed with water several times and mixed with cryoprotectants. Literature reports indicate high utility of mechanically recovered meat of different slaughter animals as a raw material for the production of surimi [1-3]. The mechanically recovered poultry meat (MRPM) is a very inexpensive raw material, sometimes of a low technological and nutritive value. Moreover, the raw material obtained by mechanical separation of meat from bones is characterised by a changeable chemical composition, low microbiological stability and high variability in functional processing properties [4-6]. However, its quality is strongly influenced by the type of equipment used for the mechanical separation. MRM is mainly applied as an additive in the production of low-price meat products, subjected to thermal processing.

Poultry myofibrillar protein concentrate, also called poultry surimi, produced using a modified technology typically applied in case of surimi, has very good technological properties, primarily a strong capacity to form strong gels after heating. Functional traits of proteins reflect their chain conformation, that is, characteristics and sequences of amino acids in polypeptide chains, the degree of their modification as well as the structure of proteins and interactions between polypeptide chains. However, the final quality of gels obtained from washed MRPM is not always identical. To a significant degree it depends on the raw material and recovery parameters, for example, the number of washings, the type of washing agent and the MRPM/water ratio. [3]. The above-mentioned factors influence not only the basic composition of the produced 
preparation, but also its functional properties. Enzymatic modification of proteins makes it possible to control their technological quality in order to modify desirable, uniform and repeatable functional properties of proteins.

Enzymatic methods are being used with an increasing frequency to control technological properties of food raw materials. In case of functional properties of proteins, the use of transglutaminase (EC 2.3.2.13) (TG) seems to be particularly promising. In meat industry, practical applications have been found for protein cross-linking with the use of TG, both endogenous, found particularly in fish meat, and that purposefully added in the course of processing [7, 8]. Cross-linking $\varepsilon$-( $\gamma$-Glu)-Lys isopeptide bonds formed under the influence of TG may both bind two different proteins or peptides and be formed within one molecule. This TG-mediated protein cross-linking creates drastic physical changes in protein-rich foods. Proteins have numerous peptide bonds, chain branches and many active amino acid radicals, typically located outside the molecule; thus, they are highly susceptible to different types of enzymatic modifications. Differences in susceptibility of proteins to the action of TG depend first of all on the content of glutamine and lysine and their availability for the enzyme, as well as conformation of proteins. The cross-linking action of TG in meat of fish and slaughter animals pertains mainly to the myosin heavy chain (MHC), which under optimal conditions supplies over $50 \%$ of all cross-linkages. Troponin T, MHC oligomers and proteins of 80 and $55 \mathrm{kDa}$ account for the other $50 \%$. In turn, actin, tropomyosin, troponin I, troponin $\mathrm{C}$ and titin ( $\beta$-connectin) are weak substrates for TG [9]. Reactions occurring under the influence of TG may be confirmed in electrophoretic analyses of proteins (SDS-PAGE) [10]. Covalent crosslinks, except for the disulphide bridges, are not opened during sample preparation for SDS-PAGE. Thus, modification of the molecular size of a protein by enzymatic cross-linking may be detected on SDS-PAGE. However, a vast majority of published studies concerned the effect of transglutaminase in proteins of fish surimi. Authors of many studies stated a weakened intensity of the myosin band with an increase in the concentration of the enzyme, resulting in an increase in the amount of assayed highmolecular proteins $[11,12]$. A lack of endogenous TG or its very low activity makes it impossible to observe similar changes in case of poultry proteins or red meat. Generally, either a lack or insignificant changes in the intensity of the MHC band contained in beef, pork or chicken meat proteins were found during setting [13].

This study is an attempt to evaluate the effect of enzymatic modification of poultry surimi on its selected functional properties. Relatively limited information is available in scientific publications on the interactions of transglutaminase with an unheated protein preparation. It is expected that the determination of changes in proteins under the influence of transglutaminase of microbiological origin (MTG) may constitute the basis for the development of methods to modify its mechanical properties. It is a crucial problem, since changes occurring under the influence of MTG-ase in the structure of raw myofibril proteins significantly determine the quality of protein gels produced as a result of heating. In turn, obtaining good-quality gels may potentially facilitate the development of novel products based on the preparation as the basic, matrix protein component.

\section{Materials and methods}

Materials and sample preparation

The basic experimental material was mechanically recovered chicken meat (MRCM) from broiler carcasses with removed breast muscles and legs obtained with the assistance of a Lima type RM 500 apparatus (Lima S.A.S.; Quimper, France). The direct experimental material was myofibrillar preparation (MP) manufactured from MRPM. The method of obtaining the preparation was adopted from the procedure described in a patent claim [14]. Raw material was rinsed with $0.169 \mathrm{~mol} / \mathrm{L}$ aqueous solution of $\mathrm{NaCl}$ and then water (MRCM/water; 1:3; w/v). Next the fat and connective tissue were separated with the assistance of sieves. Obtained preparation of myofibrillar proteins was divided into two parts. The control sample was taken from the first batch of the raw material, while the second batch was supplemented with $3 \mathrm{~g} / \mathrm{kg}$ transglutaminase preparation (MTGP) and incubated at $6-7^{\circ} \mathrm{C}$ for $1,3,5,8$ and $24 \mathrm{~h}$. Moreover, texture was analysed in myofibril samples with the addition of transglutaminase for $0.5,1.5,3,4.5,6$, 7.5, 9 and $24 \mathrm{~h}$. The difference in the protein modification time resulted from the analytical specificity of the applied research methods. The addition of transglutaminase at $3 \mathrm{~g} / \mathrm{kg}$ was found to be most advantageous [15]. In an earlier publication the following enzymatic modification parameters were applied: $0.1,0.2,0.3$ and $0.6 \%$ addition of the MTGP; time 1, 3, 5, 8 and $24 \mathrm{~h}$; and temperature of $6-7{ }^{\circ} \mathrm{C}$. It was found that a $0.2 \%$ addition of transglutaminase preparation reduced cooking loss from poultry surimi gels obtained from mechanically recovered chicken meat. However, a $0.3 \%$ concentration of the enzyme was found to be most advantageous [15].

The MP enzymatic modification was performed with the assistance of a commercial preparation ACTIVA WM by Ajinomoto Co., Ltd. (Barentz, Poland). The applied preparation contained $1 \%$ transglutaminase of microbiological origin (Streptoverticillium sp.) of 100 units/g activity and $99 \%$ maltodextrin used as the enzyme carrier (Ajinomoto's specifications). One unit was the amount of the enzyme 
which catalysed the formation of $1 \mu \mathrm{mol}$ of hydroxamic acid/min at $37{ }^{\circ} \mathrm{C}$.

\section{Determination of proximate composition}

Determination of myofibrillar preparation basic constituents was carried out with the assistance of standard methods, that is, contents of water [16] and protein according to the Kjeldahl procedure $(\mathrm{N} \times 6.25)$ [17], fat [18] (Soxhlet method) and ash [19] contents.

\section{Determination of protein solubility}

Protein solubility was tested according to Helander [20] by extracting protein from a sample $(2.0 \mathrm{~g})$ with the use of $0.1 \mathrm{M}$ phosphate buffer at $\mathrm{pH} 7.4\left(0.1 \mathrm{M} \mathrm{KH}_{2} \mathrm{PO}_{4}+\right.$ $0.1 \mathrm{M} \mathrm{Na}_{2} \mathrm{HPO}_{4} \times 12 \mathrm{H}_{2} \mathrm{O}+1.1 \mathrm{M} \mathrm{KI}$ ). Washed myofibrils were collected as a result of double washing of the muscle tissue with a phosphate buffer solution. The amount of protein dissolved in the buffer was expressed as a percentage of total protein contained in the sample. Protein analyses were performed by Kjeldahl procedure using a Kjeltec system. A factor of 6.25 was used to convert nitrogen to protein.

\section{SDS-PAGE of myofibril preparation}

Electrophoretic separation of poultry myofibril preparation in $15 \%$ polyacrylamide gel with an addition of $8 \mathrm{M}$ urea was performed according to the method of Fritz et al. [21] as modified by Pospiech et al. [22] using a Hoefer SE 250 Mighty Small unit (San Francisco, USA). The acrylamide stock solution for the separating gel was composed of $29.85 \%$ acrylamide and $0.15 \% \quad N, N^{\prime}$-methylenebisacrylamide. Each myofibril sample for SDS-PAGE was dissolved in the sample buffer containing $8 \mathrm{M}$ urea, $2 \mathrm{M}$ thiourea, $3 \%$ SDS, $75 \mathrm{mM}$ DTT, $0.05 \mathrm{M}$ Tris- $\mathrm{HCl}(\mathrm{pH}$ 6.8) and $0.05 \%$ bromophenol blue to give a final protein concentration of $1 \mathrm{mg} / \mathrm{ml}$ using the biuret assay. Next, the protein samples were heated in a dry block bath at $100{ }^{\circ} \mathrm{C}$ for $3 \mathrm{~min}$ and loaded ( $8 \mu \mathrm{g} / \mathrm{well})$ into the wells. Electrophoresis was run at a constant $20 \mathrm{~mA}$ current per gel at room temperature. The gels were stained for $1 \mathrm{~h}$ in a solution containing $0.05 \%$ Coomassie Blue R-250 in $50 \%$ methanol-10\% acetic acid and destained by diffusion in $10 \%$ methanol-7.5\% acetic acid for several hours. Quantitative analysis of separated proteins was conducted with an Image Master VDS scanning densitometer (Pharmacia Biotech), using the Image Master 1DElite version 4.00 software. Computations were based on the assumption that the area of a single protein band accounts for a percentage ratio in relation to the area of all separated proteins in a given sample on gel, which constitutes $100 \%$. Quality identification of peaks was conducted on the basis of determinations of molecular weight in kiloDaltons $(\mathrm{kDa})$ using reference protein standards by Sigma.

\section{DSC analysis}

Thermal analysis was conducted using a differential scanning calorimeter DSC 7 by Perkin-Elmer (Norwalk, USA). The raw samples of myofibril preparation were weighed (approximately $15 \mathrm{mg}$ ) into aluminium sample pans (Perkin Elmer, Norwalk, USA; No. 0219-0062). An empty capsule was used as the reference sample. The heating rate was $5{ }^{\circ} \mathrm{C} / \mathrm{min}$, within the range from 20 to $100{ }^{\circ} \mathrm{C}$. Three replications were performed with each sample. As a result of DSC analyses, thermal curves were obtained. The enthalpy of denaturation $\Delta H(\mathrm{~J} / \mathrm{g})$ and temperature of maximum transition $T\left({ }^{\circ} \mathrm{C}\right)$ were calculated with the data analysis software supplied by Perkin Elmer. Enthalpy $(\Delta H)$ was determined by measuring the area under the DSC curve and expressed in $\mathrm{J} / \mathrm{g}$ of protein. Protein analyses were performed by Kjeldahl procedure using a Kjeltec system. A factor of 6.25 was used to convert nitrogen into protein.

\section{Determination of texture}

Texture of raw protein preparation was analysed with a Texture Analyser TA-XT2i (Surrey, Great Britain) utilising, for this purpose, the method of back extrusion using an attachment of $\mathrm{A} / \mathrm{BE}$ type, with a compression disc of $40 \mathrm{~mm}$ in diameter. The sample of MP (approximately $80 \pm 5 \mathrm{~g}$ ) placed inside a cylinder of $50 \mathrm{~mm}$ in diameter was subjected to compression to the depth of $30 \mathrm{~mm}$. The behaviour of the sample preparation both during compression and during the disc return motion was analysed. The maximum force is taken as a measurement of firmness (N). The area of the curve up to this point is taken as a measurement of consistency $(\mathrm{N} \times \mathrm{s})$. The negative region of the graph, produced on probe return, is as a result of the weight of sample, which is lifted primarily on the upper surface of the disc on return, that is, due to back extrusion, and hence gives again an indication of consistency/resistance to flow off the disc. The maximum negative force is taken as an indication of cohesiveness $(\mathrm{N})$ of the sample. The area of the negative region of the curve is often referred to as the index of viscosity $(\mathrm{N} \times \mathrm{s})$ of the sample. Force-time deformation curves were obtained with a $25 \mathrm{~kg}$ load cell applied at a cross-head speed of $2.0 \mathrm{~mm} / \mathrm{s}$. The other operating conditions of the apparatus were as follows: pretest speed, $1.5 \mathrm{~mm} / \mathrm{s}$; post-test speed, $1.5 \mathrm{~mm} / \mathrm{s}$; data acquisition rate, $200 \mathrm{pps}$; and applied force, $5 \mathrm{~g}$. 
Statistical analysis

The significance of differences between means was verified statistically using the Duncan' and least significant difference (LSD) tests, while the Kruskal-Wallis tests were conducted for nonparametric data. As required two-way (ANOVA) and multivariate analyses of correlation and regression methods were used. The significance of the model was verified at the significance level $p<0.05$. Statistical analysis was performed using the STATISTICA PL v. 10.0 software by StatSoft.

\section{Results and discussion}

Basic composition

No statistically significant $(p<0.05)$ effect was observed in the supplementation with the enzymatic preparation on the chemical composition of protein preparation obtained as a result of MRCM rinsing. Prepared samples of MP were of following basic chemical composition: $84.3 \pm 0.5 \%$ water, $14.1 \pm 0.3 \%$ protein, $0.8 \pm 0.2 \%$ fat and $0.5 \pm$ $0.1 \%$ ash (mean \pm standard error; $n=4$ ).

\section{Solubility of proteins}

Solubility of proteins is an important functional property. The gelling process depends on the state of dissolution of myofibril proteins. In case of the control, MP solubility varied slightly (Fig. 1). Statistically significant differences were found only between means determined after 24-h incubation and values obtained after 1 and $3 \mathrm{~h}$. However, a different trend was found for this property in proteins subjected to enzymatic modification. In this case a gradual reduction in their solubility was observed with modification time. After $24 \mathrm{~h}$ storage solubility of proteins decreased on average by $13 \%$. The process was most dynamic in the first $3 \mathrm{~h}$ of transglutaminase action on MP proteins, since in that period solubility of proteins decreased statistically significantly by almost $6.5 \%$. Protein solubility determined in the 5 th hour of incubation was by almost $8 \%$ lower in comparison with the initial value.

The effect of an addition of the enzyme and incubation time with proteins of the preparation is better reflected in the course of solubility curves in relative units, that is, in the ratio of MP + MTGP to MP for the corresponding incubation times (Fig. 2). The course of changes in relative solubility in the function of incubation time is well reflected in the exponential Weibull curve, with the shoulder in the beginning. The curve parameters and shoulder indicate that the effect $\mathrm{Y}$ equal to relative solubility of $100 \%$ can be reached after approximately $1.4 \mathrm{~h}$ of

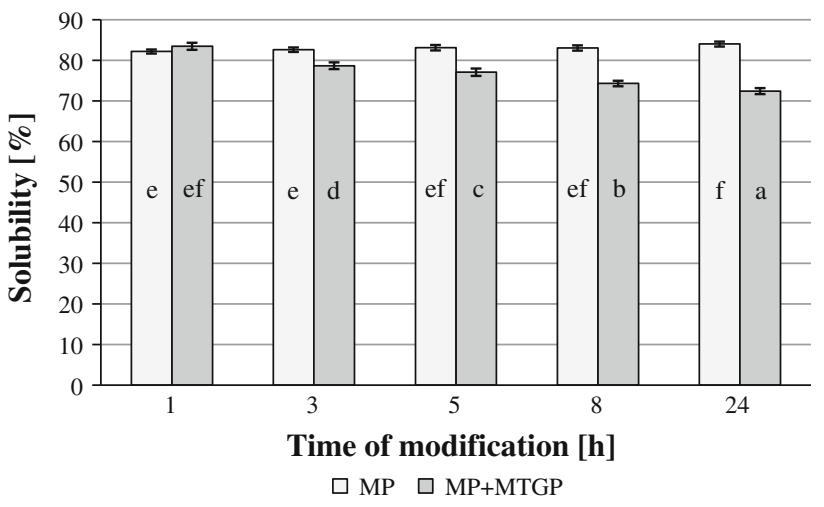

Fig. 1 Solubility of myofibril preparation proteins depending on modification time. MP myofibril preparation, $M T G P$ microbial origin transglutaminase preparation. a,...f-Identical letters denote a lack of statistically significant differences between mean values $(p<0.05$; $n=6$; error bars-standard deviation)

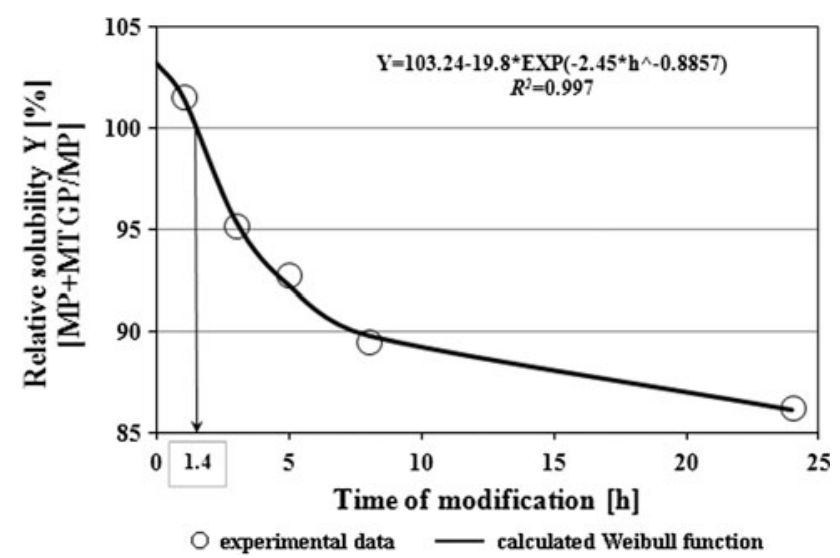

Fig. 2 The course of changes in relative solubility in the function of incubation time. $M P$ myofibril preparation, $M T G P$ microbial origin transglutaminase preparation

incubation. The following conclusions may be drawn from the parameters of the curve. Immediately after the introduction of MTGP, a slight increase occurs in the solubility of proteins in relation to MP. Solubility identical to that of the control is reached after $1.4 \mathrm{~h}$ of incubation of the preparation with an addition of the enzyme. It means that in that time at least one (or more) cross-linking bond is formed. The biggest dynamics of changes in solubility was observed up to $5 \mathrm{~h}$ of incubation, after which the slope of the curve decreases.

The two-way analysis of variance showed a significant effect of modification time $(F$-ratio $=72.8)$ and the addition of the enzyme $(F$-ratio $=750.7)$ on solubility of proteins (SP) $(p<0.05)$. It also results from multiple regression equation presented below and the standardised coefficient that both factors had a significant effect on solubility of poultry proteins. However, a bigger effect was 
shown for an addition of MTGP than for protein modification time with the enzyme.

$$
\begin{aligned}
\mathrm{SP}= & 84.262-18.822 \times x_{1}-0.173 \\
& \times x_{2}\left(R^{2}=0.795 ; p<0.0000\right)
\end{aligned}
$$

where $x_{1}$-addition (standardised coefficient $=-0.710$ ); $x_{2}$-reaction time (standardised coefficient $=-0.359$; $p$-significance level of multiple regression).

Generally, fitting the mathematical models to the experimental data indicates that the effect studied is not probabilistic or random nature. Also, the models describe trends or rules, and such experiment conducted in the other laboratory would follow similar trends of changes, whatever absolute figures would be.

Results obtained from these experiments are consistent with those presented in available publications [12, 23]. An addition of transglutaminase reduces solubility of proteins, which is ascribed to a considerable degree to the forming of intra- and intermolecular covalent bonds and polymerisation of MHC. This may be confirmed by studies on solubility of proteins in the solution containing SDS, urea and $\beta$-mercaptoethanol, which does not dissolve these bonds, that is, those formed during cross-linking of proteins under the influence of transglutaminase [24]. Also, setting time and temperature in case of fish surimi have a significant effect on the reduction in protein solubility $[25,26]$. Similar observations were reported in their study by Ionescu et al. [27], who stated an over $30 \%$ reduction in solubility of myofibril proteins, obtained by washing bovine hearts, with an increase in the amount of added enzymatic preparation from $0.05 \mathrm{~g}$ to $0.4 \mathrm{~g} \mathrm{MTG} / 100 \mathrm{~g}$ protein. In turn, with an extension of modification time to $90 \mathrm{~min}$, the reduction in protein solubility was approximately $37 \%$.

Electrophoretic analysis of myofibril preparation

The degree of protein solubility modified by addition of MTGP affected the separation pattern in the polyacrylamide gels. For better observation of proteins in the range below $42 \mathrm{kDa}$, the urea in the final concentration of $8 \mathrm{M}$ was added to the gel. Its addition in such concentration to the polyacrylamide gel changed the position of some proteins in the gel after electrophoresis. It concerned proteins with molecular weight lower than actin, especially the tropomyosin (TM). It shall appear below the actin (according to its molecular weight), but by the addition of urea, the tropomyosin is placed above actin (Fig. 3). This phenomenon is associated with the dimension of this molecule, and it was described by Penny and FergusonPryce [28], among others. The evaluation of proteins in a wide range of molecular weights (even above $205 \mathrm{kDa}$ ) was related not only with the usage of urea but also with

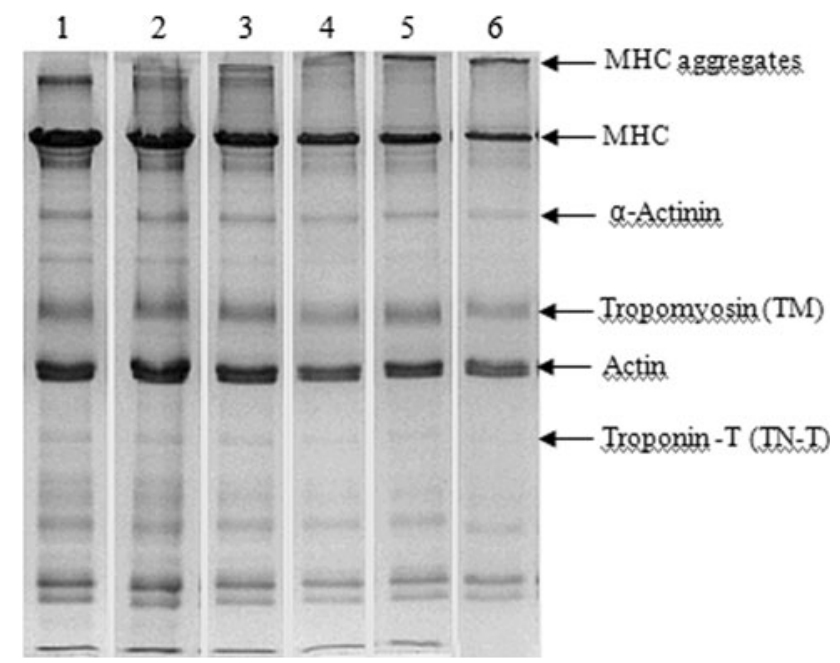

Fig. 3 Electrophoretic separation of myofibrillar preparation (MP) with the addition of transglutaminase in $15 \%$ polyacrylamide gel (SDS-PAGE) depending on modification time. Lane 1 control sample, lanes 2-6 enzymatically modified MP samples for 1, 3, 5, 8 and 24 h, respectively

the changed ratio of the acrylamide to the bisacrylamide (199:1) in $15 \%$ polyacrylamide gel. Ready-to-use commercial gels are usually $12.5 \%$ in which the acrylamideto-bisacrylamide ratio was $32: 1$. The use of polyacrylamide gels with variable ratio of $T / C$ enables the observation of high-molecular-weight (above $205 \mathrm{kDa}$ ) proteins because of large pores in the acrylamide/bisacrylamide matrix. The results of these observations are shown in Fig. 3.

On the basis of obtained densitograms, the marked effect was found for the duration of sample enzymatic modification, particularly in terms of a reduced intensity of the protein band with a molecular weight of $205 \mathrm{kDa}$, corresponding to MHC (Fig. 4). The quantitative interpretation of the observed change in the content of MP proteins, occurring under the influence of MTGP, confirmed a differentiation in the proportion of this protein band (MHC) with a molecular weight of $205 \mathrm{kDa}$, corresponding to MHC, with an extension of the modification time (Fig. 5). No decrease was found in the percentage share of actin. It is hypothesised that-similarly to the action of heat on proteins-transglutaminase causes changes by a partial development of polypeptide chains and as a consequence in an enhanced availability of hydrophobic fragments [29]. However, in other fragments of the chain protein molecules undergo aggregation, combined with a reduction in availability of hydrophobic fragments and a loss of solubility [30].

Results obtained from electrophoretic analysis for myofibril preparation subjected to the action of the enzyme are similar to those reported previously by other authors $[10,31,32]$. Proteins of comminuted chicken breast muscle 


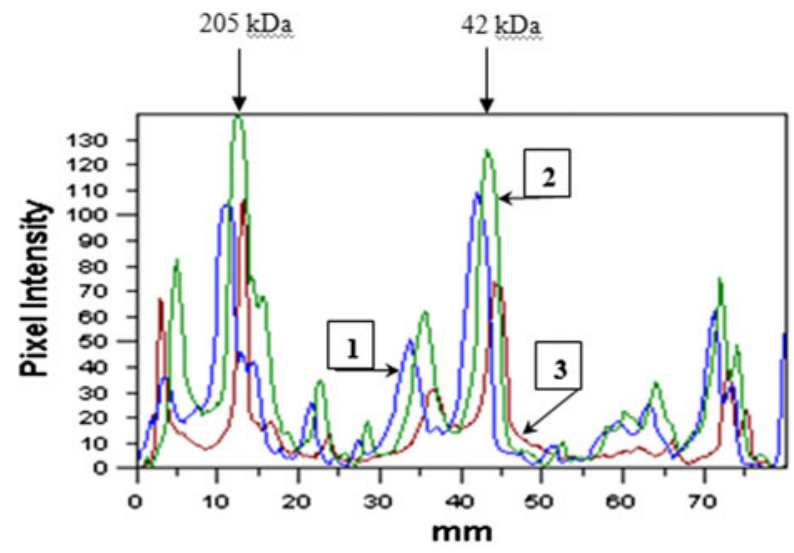

Control sample (MP)

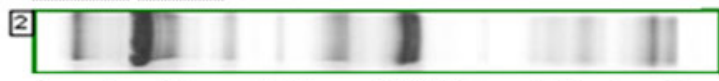

Sample with an addition of MTGP, modification lh

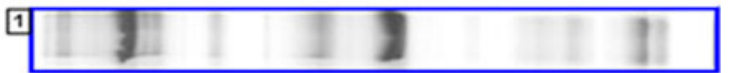

Sample with an addition of MTGP, modification $24 \mathrm{~h}$

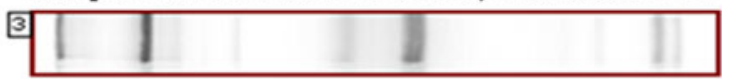

Fig. 4 Selected densitograms of electrophoretic separation of MP protein subjected to the action of MTGP for 1 and $24 \mathrm{~h}$. MP myofibril preparation, MTGP microbial origin transglutaminase preparation

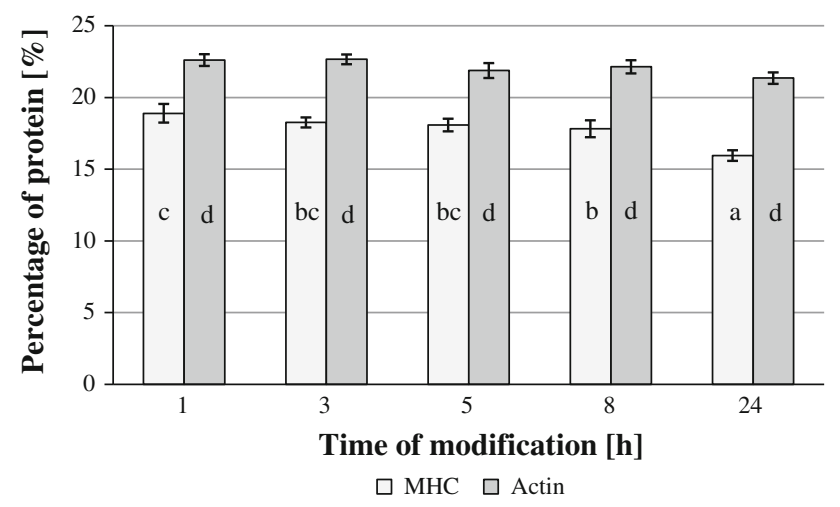

Fig. 5 Contents of myosin heavy chain (MHC) and actin in enzymatically modified myofibril preparation in the time function. $\mathrm{a}, \ldots . \mathrm{d}$-Identical letters denote a lack of statistically significant differences between mean values $(p<0.05 ; n=3$; error barsstandard deviation)

with an addition of $\mathrm{TG}$ incubated at $40{ }^{\circ} \mathrm{C}$ were characterised by a lower intensity of $\mathrm{MHC}$ and troponin $\mathrm{T}$ with an extension of incubation time (Fig. 3). No changes were observed in the actin band [31]. Similar changes in relation to myosin were earlier found in case of MRPM [32]. In contrast, no changes were found in the content of actin obtained from beef [10], chicken meat [31] and fish [33].
Table 1 The effect of an addition of enzymatic preparation and modification time on the temperature of transition of myofibril preparation

\begin{tabular}{llrl}
\hline $\begin{array}{l}\text { Type of } \\
\text { sample }\end{array}$ & $\begin{array}{l}\text { Time of } \\
\text { modification }(\mathrm{h})\end{array}$ & \multicolumn{2}{c}{ Temperature of transition $\left({ }^{\circ} \mathrm{C}\right)$} \\
\cline { 3 - 4 } & & & \multicolumn{2}{l}{$T_{2}$} \\
\hline MP & 1 & $* 57.65^{\mathrm{a}} \pm 0.19$ & $* 70.62^{\mathrm{a}} \pm 0.21$ \\
$\mathrm{MP}+$ MTGP & 1 & $57.79^{\mathrm{a}} \pm 0.18$ & $70.46^{\mathrm{a}} \pm 0.30$ \\
MP + MTGP & 3 & $57.15^{\mathrm{a}} \pm 0.11$ & $70.67^{\mathrm{a}} \pm 0.20$ \\
MP + MTGP & 5 & $56.94^{\mathrm{a}} \pm 0.22$ & $70.18^{\mathrm{a}} \pm 0.16$ \\
MP + MTGP & 8 & $57.73^{\mathrm{a}} \pm 0.38$ & $70.45^{\mathrm{a}} \pm 0.19$ \\
MP + MTGP & 24 & $57.56^{\mathrm{a}} \pm 0.25$ & $70.81^{\mathrm{a}} \pm 0.25$ \\
\hline
\end{tabular}

The same letters in columns denote not a significant difference for means at $p<0.05$ ( $n=3$; mean \pm standard deviation)

$M P$ myofibril preparation, $M T G P$ microbial origin transglutaminase preparation

* Average of all five times of modification

Analysis of thermodynamic properties of proteins

The peak temperatures $(T)$ of the transitions, providing information about unfolding and aggregation and thus reflecting thermal stability, were also recorded (Table 1). On all thermograms generated by DSC, two basic peaks of changes were recorded, where $T_{1}$ corresponds to the temperature range from 56.94 to $57.79{ }^{\circ} \mathrm{C}$ and the difference was non-significant. In case of temperatures $T_{2}$ differences in the transition temperatures were also non-significant and for all incubation times fell within the range from 70.18 to $70.81{ }^{\circ} \mathrm{C}$. Presented values of temperatures refer to myofibrillar preparation with an addition of transglutaminase. No significant differences were found in the recorded temperatures for the control sample. The mean values of $T_{1}$ and $T_{2}$ were 57.65 and $70.62{ }^{\circ} \mathrm{C}$, respectively. Also observed transformation temperatures were corresponding to the temperature of denaturation for myosin and actin. In case of samples with an addition of MTGP, we may see a certain decrease in temperature $T_{1}$ (although statistically non-significant) by approximately $1{ }^{\circ} \mathrm{C}$ (after 5-h modification) in relation to the control. A decrease in transformation temperature of myosin may indicate lower thermostability of the system. A much greater reduction in transformation temperatures of myofibril proteins obtained from bovine hearts under the influence of the enzyme was reported in their study by Ramírez-Suárez et al. [34].

The transformation temperature of myofibril proteins is influenced by the type of the washing factor, for example, sodium hydrogen carbonate, alkaline solution, sodium chloride or phosphates [1,35]. An increase in the concentration of $\mathrm{NaCl}$ added to comminuted chicken breast muscles washed with water reduced transformation temperatures of myosin and actin, as it was recorded by Kijowski and Mast [35]. In this study salt was added to 
water used in washing of MRPM. Probably, differences concerning denaturation temperatures of proteins, presented in different studies, may also result from different values of $\mathrm{pH}$ and ionic strength between tested samples, which was found in case of isolated myofibrils obtained from different types of poultry muscles [36]. Consequently, a straightforward comparison between different studies should be avoided.

The heat of transition $(\Delta H)$ associated with the heatinduced conformational changes of the myofibrillar proteins during denaturation was estimated (Fig. 6). The control after the first hour of incubation had the highest value of total enthalpy, on average amounting to $17.03 \mathrm{~J} / \mathrm{g}$ protein. It should be noted that at an addition of MTGP to proteins after $1 \mathrm{~h}$ of enzymatic modification, the value of total enthalpy was already statistically significantly lower in comparison with the control sample. A very dynamic reduction in enthalpy for MP proteins (by approximately $13 \%$ ) was observed between the 1 st and the 3rd hour of modification. In contrast, no statistically significant differences were found in the recorded values of enthalpy between the sample incubated for 8 and $24 \mathrm{~h}$. This means that in the successive analysed experimental periods these processes occur much less dynamically.

The effect of the MTGP addition on thermal properties of proteins observed in this study is similar to the results of investigations conducted by Aktaş and Kiliç [37] for myofibril preparations obtained from beef. A transglutaminase addition resulted in a statistically significant reduction in the heat of transformation corresponding to myosin. The value of $\Delta H$ determined for actin was not found to decrease. Similarly to this study, those authors stated a reduction in the transition temperature of myosin on average by approximately $1{ }^{\circ} \mathrm{C}$.

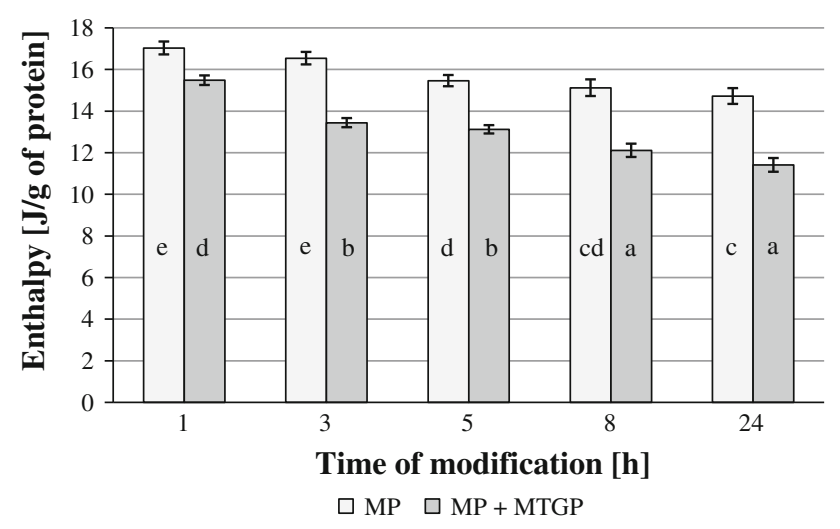

Fig. 6 Values of enthalpy of myofibril preparation proteins depending on modification time. $M P$ myofibril preparation; $M T G P$ microbial origin transglutaminase preparation. a,...d-Identical letters denote a lack of statistically significant differences between mean values ( $p<0.05 ; n=4$; error bars — standard deviation)
The presented calorimetric analysis for MP samples may confirm the recorded results and the electrophoretic analyses described above, in which a reduction was observed in the amount of myosin monomer on the basis of the disappearance of the MHC band on densitograms. It was found that the calculated value of $\Delta H$ for actin was similar for all the analysed samples, amounting on average to $2.06 \mathrm{~J} / \mathrm{g}$ protein. This value did not change significantly with the passage of modification time. This may mean that changes in enthalpy determined on the basis of DSC analysis pertain to the first peak, which corresponds to the denaturation of myosin. The main changes in thermal properties of myofibril proteins treated with transglutaminase are ascribed to the polymerisation of myosin. On SDS-PAGE transglutaminase was found to polymerise myosin. It is a known fact that the variety of proteins found in the analysed system has a significant effect on the degree of protein polymerisation occurring under the influence of transglutaminase [38, 39]. It is also known that protein polymerisation is an exothermal process and leads to a reduction in the value of enthalpy, which is the process taking place under the influence of transglutaminase. Changes in the heat of transition are thought to be related to the conformational changes caused by intra- and/or intermolecular cross-linking catalysed by MTG, whereas changes in the peak temperature are regarded as being due to the changes in thermal stability [34].

\section{Texture of the myofibrillar preparation}

Values of texture parameters determined for MP with an addition of the enzyme were much higher than for the control samples (Table 2). This could be observed already in the second control time. A very dynamic increase was recorded in the values of all texture parameters in the period from 1.5 to $7.5 \mathrm{~h}$ of modification. The highest numerical values of obtained indexes were determined after $24 \mathrm{~h}$ of the preparation incubation with the enzyme. It was found that the above values increased approximately twofold in the period from 1.5 to $24 \mathrm{~h}$ of setting. In turn, the coefficient of dynamic viscosity was found to increase as much as fourfold.

Interesting information on the mechanism of observed changes in texture under the influence of MTGP may be supplied by the analysis of their course performed for relative values, that is, percentages in relation to samples with no enzyme added (Fig. 7). It results from the data given in the graph that relative changes in the analysed parameters may be described with a sufficient accuracy using a common logarithmic function. Slopes of straight lines indicate that most intensive dynamics of changes may be observed for viscosity of model samples (137.8). It is of interest that in case of cohesion, despite the lowest 
Table 2 The effect of an addition of enzymatic preparation and modification time on texture parameters of myofibril preparation

\begin{tabular}{|c|c|c|c|c|c|}
\hline \multirow[t]{2}{*}{ Type of sample } & \multirow[t]{2}{*}{ Time of modification $(\mathrm{h})$} & \multicolumn{4}{|c|}{ Texture parameters } \\
\hline & & Firmness (N) & Consistency $(\mathrm{N} \times \mathrm{s})$ & Cohesiveness $(\mathrm{N})$ & Index of viscosity $(\mathrm{N} \times \mathrm{s})$ \\
\hline MP & 0.5 & $18.0^{\mathrm{i}} \pm 0.8$ & $238.1^{\mathrm{m}} \pm 2.2$ & $-13.3^{\mathrm{a}} \pm 0.3$ & $48.7^{\mathrm{k}} \pm 0.7$ \\
\hline $\mathrm{MP}+\mathrm{MTGP}$ & & $18.1^{\mathrm{i}} \pm 0.5$ & $242.6^{1} \pm 2.1$ & $-14.3^{\mathrm{bc}} \pm 0.5$ & $49.2^{\mathrm{k}} \pm 0.8$ \\
\hline MP & 1.5 & $19.3^{\mathrm{gh}} \pm 0.6$ & $250.5^{1} \pm 2.2$ & $-14.0^{\mathrm{b}} \pm 0.4$ & $59.2^{\mathrm{j}} \pm 0.8$ \\
\hline $\mathrm{MP}+\mathrm{MTGP}$ & & $24.4^{\mathrm{f}} \pm 0.7$ & $325.3^{\mathrm{g}} \pm 3.0$ & $-15.9^{\mathrm{cd}} \pm 0.6$ & $102.5^{\mathrm{g}} \pm 1.1$ \\
\hline MP & 3.0 & $20.6^{\mathrm{g}} \pm 0.7$ & $264.9^{j} \pm 2.5$ & $-15.5^{\mathrm{c}} \pm 0.5$ & $67.5^{\mathrm{h}} \pm 0.9$ \\
\hline $\mathrm{MP}+\mathrm{MTGP}$ & & $31.8^{\mathrm{e}} \pm 0.6$ & $366.5^{\mathrm{f}} \pm 3.1$ & $-19.9^{\mathrm{e}} \pm 0.6$ & $173.8^{\mathrm{f}} \pm 1.2$ \\
\hline MP & 4.5 & $20.5^{\mathrm{g}} \pm 0.4$ & $232.6^{\mathrm{n}} \pm 2.8$ & $-15.4^{\mathrm{c}} \pm 0.4$ & $68.2^{\mathrm{h}} \pm 0.7$ \\
\hline $\mathrm{MP}+\mathrm{MTGP}$ & & $36.8^{\mathrm{d}} \pm 0.7$ & $471.0^{\mathrm{d}} \pm 4.0$ & $-24.8^{\mathrm{f}} \pm 0.7$ & $204.0^{\mathrm{d}} \pm 1.5$ \\
\hline MP & 6.0 & $20.8^{\mathrm{g}} \pm 0.6$ & $251.8^{1} \pm 2.4$ & $-16.5^{\mathrm{d}} \pm 0.5$ & $66.8^{\mathrm{h}} \pm 0.5$ \\
\hline $\mathrm{MP}+\mathrm{MTGP}$ & & $37.1^{\mathrm{d}} \pm 0.8$ & $464.8^{\mathrm{e}} \pm 3.3$ & $-24.5^{\mathrm{f}} \pm 0.6$ & $202.6^{\mathrm{e}} \pm 2.2$ \\
\hline MP & 7.5 & $18.7^{\mathrm{hi}} \pm 0.4$ & $263.9^{\mathrm{k}} \pm 2.8$ & $-15.6^{\mathrm{c}} \pm 0.4$ & $66.9^{\mathrm{h}} \pm 0.9$ \\
\hline $\mathrm{MP}+\mathrm{MTGP}$ & & $41.9^{\mathrm{b}} \pm 0.8$ & $566.1^{\mathrm{c}} \pm 4.7$ & $-26.3^{\mathrm{g}} \pm 0.7$ & $301.4^{\mathrm{b}} \pm 5.7$ \\
\hline MP & 9.0 & $20.0^{\mathrm{g}} \pm 0.9$ & $272.6^{\mathrm{i}} \pm 2.1$ & $-15.9^{\mathrm{cd}} \pm 0.6$ & $67.5^{\mathrm{h}} \pm 0.7$ \\
\hline MP + MTGP & & $40.6^{\mathrm{c}} \pm 0.7$ & $577.4^{b} \pm 6.3$ & $-26.7^{\mathrm{g}} \pm 0.5$ & $291.7^{\mathrm{c}} \pm 2.8$ \\
\hline MP & 24.0 & $20.6^{\mathrm{g}} \pm 0.8$ & $280.0^{\mathrm{h}} \pm 3.4$ & $-16.2^{\mathrm{cd}} \pm 0.5$ & $65.1^{\mathrm{i}} \pm 0.8$ \\
\hline MP + MTGP & & $48.2^{\mathrm{a}} \pm 0.8$ & $674.1^{\mathrm{a}} \pm 4.5$ & $-27.7^{\mathrm{h}} \pm 0.8$ & $416.5^{\mathrm{a}} \pm 3.4$ \\
\hline
\end{tabular}

Different letters in columns denote a significant difference for means at $p<0.05(n=6$; mean \pm standard deviation)

$M P$ myofibril preparation, MTGP microbial origin transglutaminase preparation

Fig. 7 The course of changes in relative values of texture parameters of myofibril preparation with an addition of transglutaminase depending on modification time

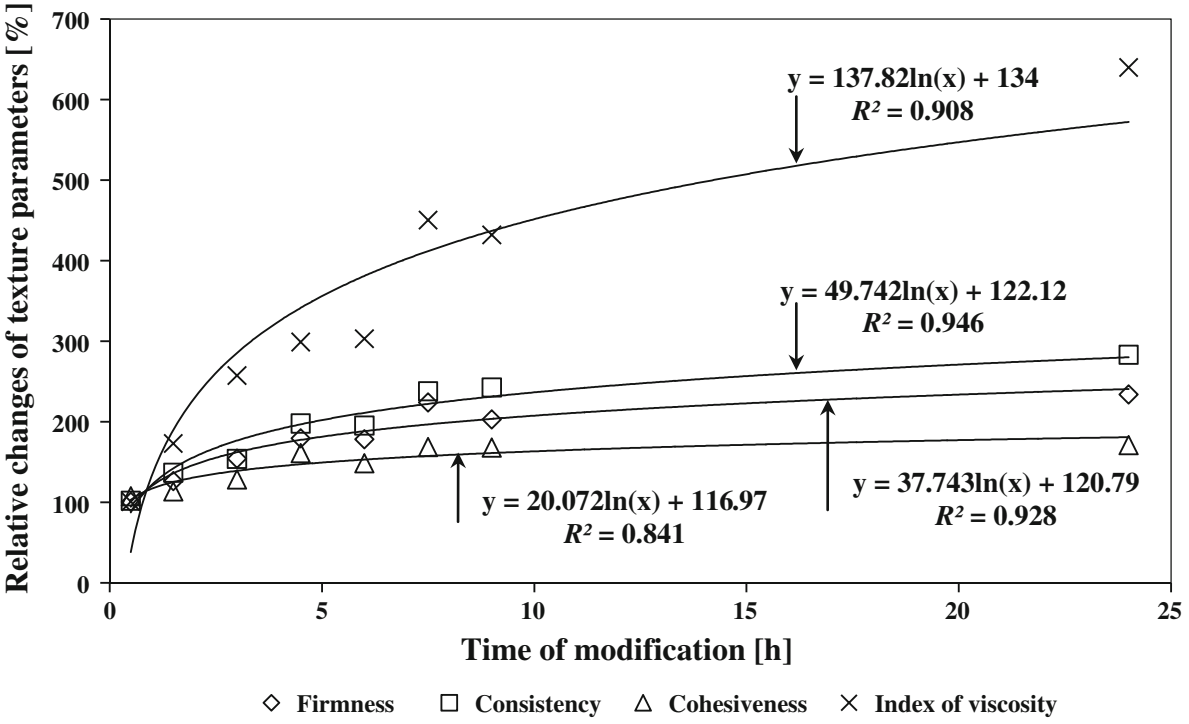

1.34, for cohesion being 1.49 and being highest for viscosity at 1.82 .

Analysis of variance concerning the effect of an addition of the enzyme and modification time showed a significant effect of both factors on all the analysed texture parameters ( $F$-ratio $>$ critical $F$ for significance level of $p<0.05$ ). Also, the investigated texture properties of MP subjected to the action of the enzyme turned out to be mathematically correlated at the significance level $\mathrm{p}<0.05$. Rather, high values of the correlation coefficients were found between the sample with MTG addition and the determined texture 
Table 3 Coefficients of linear correlation between analysed functional characteristics determined for enzymatically modified myofibril samples $(n=15 ; p<0.05)$

\begin{tabular}{lcccccr}
\hline Variable & Solubility & Enthalpy & Firmness & Consistency & Cohesiveness & Index of viscosity \\
\hline Solubility & - & 0.886 & -0.904 & -0.887 & 0.920 & -0.870 \\
Enthalpy & 0.886 & - & -0.952 & -0.855 & 0.926 & -0.929 \\
Firmness & -0.904 & -0.952 & - & 0.958 & -0.980 & 0.971 \\
Consistency & -0.887 & -0.855 & 0.958 & - & -0.955 & -0.961 \\
Cohesiveness & 0.920 & 0.926 & -0.980 & -0.955 & - & -0.929 \\
Index of viscosity & -0.870 & -0.929 & 0.971 & 0.961 & -0.929 & - \\
\hline
\end{tabular}

parameters of poultry surimi, that is, firmness at 0.81 , consistence 0.85 , cohesiveness -0.71 and index of viscosity of 0.91 , respectively.

Addition of an enzymatic preparation containing microbial transglutaminase significantly changes properties of proteins in the myofibril preparation. The importance of the effect of transglutaminase on interactions between analysed functional properties of unheated proteins may also be indicated by the established correlation coefficients (Table 3). Determined coefficients for the control were in most cases lower and frequently statistically non-significant. An addition of the enzyme to MP evidently strengthened these interactions, which was manifested by the calculated statistical significance between all the investigated properties. This shows the comprehensive character of changes occurring in the tested model protein systems and confirms the advisability of such studies.

\section{Conclusions}

A condition which needs to be met for the extension of MP availability will be to know its functional and technological properties with insight into their extended characteristics in terms of physico-chemical properties. Enzymatic modification of MP properties, for example, by transglutaminase, makes it possible to modify these properties. Such intensive conformation changes occurring in proteins under the influence of transglutaminase result from the forming crosslinkages within one molecule of protein or between proteins and peptides. Intensification of the protein polymerisation process, caused by the effect of the added enzyme, is reflected in the results of the presented analyses. An addition of MTGP reduced solubility of MP proteins. The degree of solubility of modified proteins also influenced their separation and the results obtained from electrophoretic densitograms. On their basis we may observe a marked effect of modification time on the intensity of the MHC band. Quantitative analysis of changes in the proportions of myofibril isolate proteins under the influence of MTGP confirmed variation in this particular fraction of proteins in tested samples. An addition of transglutaminase to proteins of raw MP resulted also in a reduction in denaturation temperature of myosin and the value of enthalpy, as well as an increase in sample elasticity. It was shown that structural changes in MP proteins occurred most intensively in the initial period of modification, that is, up to approximately $3-4 \mathrm{~h}$.

On the basis of collected results, we may infer on the technological advisability of MTGP addition in order to improve functional properties of proteins, particularly texture. However, we need to bear in mind the complexity of the effect of many factors, which may determine the final effect of their modification. Obtained results may be used to model the structure of meat products based on myofibrillar proteins modified by transglutaminase. Thanks to the identification of appropriate conditions for the interaction of the enzyme with poultry proteins, a repeatable model of proteins with advantageous technological properties may be created, at the same time enhancing its potential rational utilisation.

Open Access This article is distributed under the terms of the Creative Commons Attribution License which permits any use, distribution, and reproduction in any medium, provided the original author(s) and the source are credited.

\section{References}

1. Yang T, Froning G (1994) Evaluation of protein functionality in alkali and nonalkali surimi processed mechanically deboned chicken meat. J Muscle Foods 5:221-232

2. Kijowski J, Richardson RI (1996) The effect of size, connective tissue and cooking regime upon properties of washed mechanically recovered broiler beat. Int J Food Sci Technol 31:37-44

3. Stangierski J, Kijowski J (2000) Optimization of conditions for myofibril preparation from mechanically recovered chicken meat. Nahrung/Food 44:333-338

4. Trindade MA, Felicio PE, Castillo CJC (2004) Mechanically separated meat of broiler breeder and white layer spent hens. Sci Agric 2:234-239

5. Negrão CC, Mizubuti IY, Morita MC (2005) Biological evaluation of mechanically deboned chicken meat protein quality. Food Chem 90:579-583

6. Serdaroğlu M, Turp GY (2005) Effects of deboning methods on chemical composition and some properties of beef and turkey meat. Turk J Vet Anim Sci 29:797-802 
7. Murphy SC, Gilroy D, Kerry JF, Buckley DJ, Kerry JP (2004) Evaluation of surimi, fat and water content in a low/no added pork sausage formulation using response surface methodology. Meat Sci 66:689-701

8. Serrano A, Cofrades S, Colmenero FJ (2004) Transglutaminase as binding agent in fresh restructured beef steak with added walnuts. Food Chem 85:423-429

9. Kishi H, Nozawa H, Seki N (1991) Reactivity of muscle transglutaminase on carp myofibrils and myosin. Bull Japan Soc Sci Fish 57:1203-1206

10. Dondero M, Figueroa V, Morales X, Curotto E (2006) Transglutaminase effects on gelation capacity of thermally induced beef protein gels. Food Chem 99:546-555

11. Sakamoto H, Kumazawa Y, Toiguchi S, Eguro K, Soeda T, Motoki M (1995) Gel strength enhancement by addition of microbial transglutaminase during onshore surimi manufacture. J Food Sci 60:300-304

12. Ashie INA, Lanier TC (1999) High pressure effects on gelation of surimi and turkey breast muscle enhanced by microbial transglutaminase. J Food Sci 64:704-708

13. Niwa E (1992) Chemistry of surimi gelation. In: Lanier TC, Lee CM (eds) Surimi technology. Marcel Dekker, New York, pp 389-427

14. Kijowski J, Stangierski J, Magnuski T, Pikul J (1996) Method of obtaining myofibril concentrate. Polish Patent Pl 169727 B1

15. Stangierski J, Kaczmarek A (2012) Effects of transglutaminase modification on quality of poultry surimi obtained from mechanically recovered chicken meat. Fleischwirt Int 6:69-73

16. PN-ISO 1442:2000 Meat and meat products. The determination of water. Reference method. Polish Committee for Standardization. Warszawa, Poland

17. PN-A-04018:1975/Az3:2002 Food and Agricultural products. Protein determination by the Kjeldahl method and conversion to protein content. Polish Committee for Standardization. Warszawa, Poland

18. PN-ISO 1444:2000 Meat and meat products. The determination of fat content. Polish Committee for Standardization. Warszawa, Poland

19. PN-ISO 936:2000 Meat and meat products. The determination of ash content. Polish Committee for Standardization. Warszawa, Poland

20. Helander EA (1961) Influence of exercise and restricted activity on the protein composition of skeletal muscles. Biochem $\mathrm{J}$ 78:478-482

21. Fritz JD, Schwartz DR, Greaser ML (1989) Factors affecting polyacrylamide gel electrophoresis and electroblotting of highweight myofibrillar proteins. Anal Biochem 180:205-210

22. Pospiech E, Greaser M, Mikołajczak B, Szalata M, Łyczyński A (2000) Degradation and release of titin in pork muscles. In: Proceedings of the 46th ICoMST, Buenos Aires, Argentina, 4.I-P1, pp 426-427

23. Gómez-Guillén MC, Montero P, Solas MT, Pérez-Mateos M (2005) Effect of chitosan and microbial transg; utaminase on the gel forming ability of horse mackerel (Trachurus spp.) muscle under high pressure. Food Res Int 38:103-110

24. Benjakul S, Visessanguan W, Pecharat S (2004) Suwari gel properties as affected by transglutaminase activator and inhibitors. Food Chem 85:91-99

25. Montero P, Pérez-Mateos M, Solas T (1997) Comparison of different gelation methods using washed sardine (Sardina pilchardus) mince: effects of temperature and pressure. J Agric Food Chem 45:4612-4618

26. Benjakul S, Visessanguan W (2003) Transglutaminase-mediated setting in bigeye snapper Surimi. Food Res Int 36:253-266

27. Ionescu A, Aprodu I, Daraba A, Porneala L (2008) The effects of transglutaminase on the functional properties of the myofibrillar protein concentrate obtained from beef heart. Meat Sci 79:278-284

28. Penny IF, Ferguson-Pryce R (1979) Measurement of autolysis in beef muscles homogenates. Meat Sci 3:121-134

29. Yongsawatdigul J, Piyadhammaviboon P (2005) Effect of microbial transglutaminase on autolysis and gelation of lizardfish surimi. J Sci Food Agric 85:1453-1460

30. An H, Peters MY, Seymour A (1996) Roles of endogenous enzymes in surimi gelation. Trends Food Sci Technol 7:321-326

31. Lantto R, Puolanne E, Katina K, Niemisto M, Buchert J, Autio K (2007) Effect of laccase and transglutaminase on the textural and water-binding properties of cooked chicken breast meat gels. Eur Food Res Technol 225:75-83

32. Akamittath JG, Ball HR Jr (1992) Transglutaminase mediated polymerization of crude actomyosin refined from mechanically deboned poultry meat. J Muscle Foods 3:1-14

33. Rawdkuen S, Benjakul S, Visessanguan W, Lanier TC (2004) Chicken plasma protein affects gelation of surimi from bigeye snapper (Priacanthus tayenus). Food Hydrocoll 18:259-270

34. Ramirez-Suarez JC, Xiong YL, Wang B (2001) Transglutaminase cross-linking of bovine cardiac myofibrillar proteins and its effect on protein gelation. J Muscle Foods 12:85-96

35. Kijowski J, Mast MG (1988) Effect of sodium chloride and phosphates on the thermal properties of chicken meat proteins. J Food Sci 53(367-370):387

36. Xiong YL, Brekke CJ, Leung HK (1987) Thermal denaturation of muscle proteins from different species and muscle types as studied by differential scanning calorimetry. Can Inst Food Sci Technol J 20:357-362

37. Aktaş N, Kiliç B (2005) Effect of microbial transglutaminase on thermal and electrophoretic properties of ground beef. LWTFood Sci Technol 38:815-819

38. Ramírez-Suárez JC, Xiong YL (2003) Effect of transglutaminaseinduced cross-linking on gelation of myofibrillar/soy protein mixtures. Meat Sci 65:899-907

39. Trespalacios P, Pla R (2007) Synergistic action of transglutaminase and high pressure on chicken meat and egg gels in absence of phosphates. Food Chem 104:1718-1727 